\title{
Empirical Identity as Dimension of Development in Africa: With Special Reference to the Igbo Society of South-east of Nigeria
}

\author{
Chigozie Nnebedum, M.A, Ph.D, Th.D \\ WiEGE Catholic University, Linz, Austria
}

Doi: $10.2478 / \mathrm{mjss}-2018-0039$

\begin{abstract}
Identity, as discussed in this paper, is seen as a phenomenon which is constantly changing under certain circumstances. From empirical point of view, the identity of man is influenced by the environment through experience and unconscious socialization; it is continually modified by the individual's encounter with the world. The aim of this work is to analyse the intricacies involved in understanding the situation and mentality of the Igbos as far as identity is concerned and to determine how this hampers or helps in the development of the Igbo/African society. In this work 'identity' as a means of development with regard to the Igbo people of South-East Nigeria is treated. The work is methodically qualitative. It analyses literatures and different views on identity and tailors the discussion of development along the lines of hermeneutical approach to subjective experiences. The Igbos and Africans find themselves sometimes in the danger of a mixture of identity. This is the case with most of the Igbo people who are scattered all over the world and who are becoming more foreign in their trends and ways of life. Being unable to maintain a definite identity, one is lost in the politics of development. Those who still hang on to pure imitation of the western life are jeopardizing their autonomy and by extension, frustrating development of the African society. Rediscovering the Igbo/African Identity and putting it to the service of development in the African continent is the task of the Africans themselves.
\end{abstract}

Keywords: Identity, development, culture, Africans-Igbos, slavery

\section{Introduction}

Identity is a very important point in the discussion on development. It has more to do with selfrealization, autonomy and diversity than a forced adaptation of one's character and behaviour to a foreign culture. In talking about African development in general one should not lose sight of the importance of identity.

This work is an exposé of the problem of empirical identity with regard to the Africans in general and Igbo people of South-East of Nigeria in particular. These problems can be tabulated into three categories:

a) The impact of neo-liberalism

b) The impact of colonialism and Post colonialism

c) The impact of post modern theory

The impact of neo-liberalism in the area of consumption of goods and services has torn the traditional way of life and cultural values apart. Dependency on the offers of the neo-liberalisation tendencies jeopardises the efforts to develop indigenous alternatives to goods and services. One witnesses less or no improvement in the way we brew our local beers, bottle our local soft drinks, modernise our local musical instruments and improve on our building technology. The discussion on 'Global Governance' is a multifaceted one which does not always enjoy a general agreement in its models and structures. The role of the developed world in the development of the underdeveloped world is not always based on honesty, though sometimes the opposite could be the case 
(Bauman, 1992).). It is the vulnerability of a society that makes outside intervention or occupation possible. In stead of pursuing their own gains, the western states can help the developing countries to stand on their feet through the exchange and provision of their scientific and technological advancement and envisage programmes for development based on the principles of democratic fairness (Ziai, 2000). There is a need for the Igbos to discover their commercial potentials. When these potentials are discovered, how do we put these into practice without being radical in our effort to limit the effect of the westerners' support?

The impact of colonialism dates back to the era of the white men on the soil of Africa. Through slavery many Africans and among them Igbos were either sold or kidnapped abroad. These carried along with them their cultural heritage which they imparted to their then immediate generations. It may be said that through slavery and colonialism, the Western world introduced migration to the African world. The colonial rule affected mostly the religious and governmental culture of the Africans and the Igbos in particular. Most of the religious practices of the Igbos were termed fetish by the colonial missionaries and the governmental structures and many social affairs were rejected as barbaric. In other words, all those activities which are not in the favour of the Western imaginations are either rejected or are modified tremendously. Sometimes they are tampered with so much that they lose their original meaning and value (Ziai, 2000). This touches the identity of the Africans and the Igbos in particular.

\section{Presentation of Problem}

How can we make the post colonial era an era free from foreign identity? In the area of identity and fair dealing, how can we, as Igbos/Africans present and compose ourselves to prove that human beings are the same; that the difference is that some countries are developed while some are underdeveloped? (Ziai, 2000).

The post modern theory impact is considered as the impact that most affects the identity of a person. With all its enticing factors which encourage adaptation to the foreign cultures, the post modern syndrome harms the identity of the Africans and Igbos in particular. Having said that, the question is: how do these factors affect the identity of the people and how do they contribute to the crisis of identity? Culture is seen and considered as a dimension of identity. How do these factors affect the culture of the people and what are those cultural structures that are necessary for the formation of identity? To discover oneself in the society is to be conscious of one's identity amidst the multiple cultures and options offered by the complications in the world. Man continues to develop his world. Development in the post modern time is supposed to be an on-going activity which is dependent on the manpower of the society and its interest. However, one may tend to believe the above assertion because there are reasonable progresses in the development of the third world countries, but there are still enough to be done. This is because globally speaking, the level of development the western countries have achieved is much and if the gap between the developed and developing countries could be bridged, then the poor development in the developing countries will be minimal.

For a constant and grass-rooted development to be in place, the arrangement and mentality of the people ought to be more homely than foreign. How do we arrange the mentality of the Igbo man which is more or less formed according to the western culture to be basically African while maintaining a balance with the western culture? One of the major means of achieving this is to ask the question 'what do we mean by development'? This is very important because when some people refer to 'development' they mean the opposite of what they want to convey (Esteva, 2006). When we talk of development, it has to come out of the interest and yearning of the people because its power and effectiveness depend on the acceptance by the host. It does not depend entirely on the "heterogeneous definitions of reality imposed upon them by the developers." (Esteva, 1991: 75). One of the aims of development is to transform the condition of life in a given society into a more productive and progressive one while giving room for the retention of basic identity of the people. It is not a project aimed at disciplining the people otherwise that will be another form of oppression in form of authoritative power. 


\section{Aims and Objectives}

The underdevelopment witnessed in the world especially among developing countries, of which Nigeria is one, revolves around economic crisis, hunger and poverty.

This work has three main aims and objectives: The first one is to demonstrate that each can contribute to the development of the nation in one way or the other by applying self determination. Taking the Igbo community of the eastern part of Nigeria as a case study, the work aims at presenting identity as a veritable tool towards achieving the much needed development in the Igbo society. The imitation of the western way of life has its limitations. First of all, as African and Igbo in particular, one has different mentality and behaviour. As a nation, Nigeria is different from other countries, and as a continent Africa is different from Europe. This being put categorically, it follows that the potentials can not be the same. To develop our society along the line of the methods and ways of the western world will be to deny the obvious. To rely solely on the help from the outside world to develop our society will be to admit and give credence to neo-liberalism whose commercial position is, sometimes, hypocritical.

The second aim of the work is directed towards strengthening those characteristics we have in the Igbo society and Nigeria at large, such as culture which could help to put us in the right direction towards development. This work analyses the obstacles involved in achieving this such as migration, and loss of identity and aims at presenting a road map toward a rediscovering of the African/lgbo identity.

The third aim of this work is 'conscience-raising campaign' which aims at addressing the Igbo potential migrants who want to leave Nigeria for the so called greener pastures and those who have already migrated. By leaving, the work forces are lost. Most of them are well educated and trained persons. Those who are already abroad need think home and contribute their quota towards development of the home front. This is possible if one thinks of one's identity.

\section{Formal Method and Procedure}

The method of the work is, due to observations, interpretations and hermeneutic approaches, basically qualitative but a series of methods are involved in it. We use the expository and analytical method since the work has something to do with human culture and its conflux with one another. A descriptive analysis is applied to portray the core meaning of some of the terms and themes used in this work since they may appear foreign to the reader. The work has a tilting towards socio-political development of man and so it makes use of both the empirical impetus and theoretical impulses of social sciences.

\section{Explanation of the Terms}

In order to understand the main terms as well as the focus of this topic, it is pertinent to attempt an explanation of the terms used in the work. The term 'identity' may be confusing because of the danger of referring to it simply as 'a distinguishing mark that separates one thing or person from another'. The country 'Nigeria' and the ethnic group 'Igbo' need to be presented to the reader so as to avoid the danger of grouping all within the common nomenclature - Africa.

\subsection{Identity}

There is no unified definition of identity. Different authors have different definitions. Mathematically, identity means sameness, two things matching each other, that is, they are the same. In this sense one can refer to $\mathbf{2}=\mathbf{2}$ or $\boldsymbol{x}=\boldsymbol{x}$ as identical respectively. (This is further referred to as 'same numbers' or 'letters'). In human beings, there is what is referred to as 'identical resemblance', that is, when two people are seen as resembling each other. But unlike in numbers or letters, human beings, irrespective of their resemblances, have particular and peculiar "identities" and qualities which are not influenced by external resemblances.

Identity defines a person as an individual, precisely as a unique and unmistakable person. 
This type of understanding of identity can only be arrived at by defining the person as individual and as a member of a given society. Many Sociologists have attempted an explication or a definition of the term "identity" as a scientific terminology. The views of few of them are presented below:

For Lothar Krappmann (1993), Identity is determined and transmitted through language. He argued that identity is first of all communicated by an individual with his/her fellow through language and this communication is unique in every situation.

For Hans-Peter Frey (1987), "identity is seen as a self-reflexive process of the individual. The person presents his or her identity from the numerous experiences he or she has had." (Frey, 1987: 21)

According to George Herbert Mead (1998), identity of a person is an on-going affair. It develops from language. He maintains that there is no identity at birth and so a person develops it within the experiences in the society and daily activities (Mead, 1998: 177).

The definition that has captured the trend in which this work is following is the one that asks the basic question "who am I". "Identity is the overall answer given to the question: who am I" (Reinhold, 1992: 247).

This definition, from Reinhold (1992), focuses on one seeing oneself as an individual. The question extends to include: 'what does it mean to be this or that person that I am'? 'what does the other person (people) think of me'?

Among many people in the world, one notices that there is lack of self-definition. This stems from the fact that there are a lot of imitation of the 'other' and a false presentation of the self. This can be witnessed in almost every aspect of life: religion, cultural, political, economic etc. Thus identity is defined as: "The full agreement of person or thing with what he/she or it represents." (Brockhaus Enzyklopädie, 2006: 94). This is an issue of self-definition. One is, in reality, what one claims to be not by saying it but by representing it. An African is an African not just by saying it but by living it. The absence of authentic cultural values and explicit characteristics is a contradiction to the identity of a person.

\subsection{Nigeria}

Nigeria is the name of the biggest and most populous country in Africa. It is located west of Africa and has a total landmass of 923,768 square kilometres. It is bordered to the north by Niger, in the east by Chad and Cameroon, and in the west by Benin. The land covers 910,768 square kilometres and water 13,000 square kilometres. The country has 36 federal states and a federal capital territory named Abuja. Lagos was the former capital city. With about 250 ethnic groups, each with it own language, and a population of about 182 million inhabitants (National Population Commission, 2017), Nigeria could be said to be a pluralistic country. It has three main religions: Christianity, Islam and a small percentage of traditional religion practitioners.

Nigerian economy is one of the strongest in the whole of Africa. Basically, Nigeria is one of the world's major suppliers of oil. Agricultural produce is also a source of income for the country. One cannot mention the country Nigeria without reference to her vast oil deposit. Other economically valuable minerals found in Nigeria are, coal, tin and columbite. ${ }^{1}$ Petroleum was first discovered in 1956 and most of the oil comes from onshore fields in the Niger delta which is in the southern part of Nigeria. $1^{\text {st }} 1960$.

The country was formerly under the British colony but gained her independence on October

\section{$5.3 \lg b o$}

The name 'Igbo' or 'Ibo' refers to the ethnic group found in Nigeria on the Western Coast of Africa. The Igbos form the greater population of the then Republic of Biafra. ${ }^{2}$ The Igbo people are dark-

\footnotetext{
${ }^{1}$ This is an iron-bearing mineral that accompanies tin.

${ }^{2}$ This is the name of a secessionist state in the south-eastern Nigeria. It was regarded as a Republic though not generally accepted by many nations. Biafra was mainly inhabited by the Igbo people and existed only for three years (1967 -1970). It was defeated in the Nigerian Civil War.
} 
skinned people from the Negro race "who might have originated in an area along the latitude of Asselar and Khartoum in Sudan, but who migrated to their present sites since the second or third millennium before Christ." (Ikeh, 1986: 3 )

This ethnic group is quite unique from other ethnic groups in Nigeria in many ways ranging from their music, religion, stories, proverbs, etc to their commercial prowess. Their general way of life is so obvious that members of the other ethnic groups in Nigeria can easily notice and recognise an Igbo person.

The identity of the lgbo person is portrayed in the general philosophy of the Igbo and illustrated in the cultural heritage of the people. This heritage depicts the fundamental understanding and belief of the Igbo when it comes to matters like birth, life, death, spirit, dignity, existence, power, mystery etc. The sacredness of life in the Igbo community is a heritage of honour passed from generation to generation. This heritage sees life from three but unified points of view thus: the bond with the ancestors who are dead, the brotherhood among those living, and the extension of hope for those unborn who will continue the tradition. Giving this understanding of life for the Igbo people, polygamy is not only allowed but cherished because by marrying many wives, many children could be born to achieve a greater solidarity with the ancestors, the living and the unborn.

The people of the Igbo tribe recognise the right and freedom to live, work, speak one's mind, uphold moral values and move about to fend for oneself. These could be seen as instruments of development in a society where the community and individuals complement each other. Perhaps it could be said that because the Igbo people recognise the freedom and right to move about to fend for oneself, they are to be found in every corner of the world where foreigners are accepted or tolerated.

\section{Crisis of Identity}

It is unfortunate to think that someone has nothing to do with the land of his or her birth. This is the case with most of the lgbo people who are scattered all over the world and who are becoming more foreign in their trends and ways of life. Among Africans, especially the Igbo people, there is a crisis of identity because of what they aspire to achieve. Many Africans are homeless, not because they do not have houses, but because of lack of intrinsic identity among them. One may not be entirely wrong to say that those Africans who are not sure of where to belong are only Africans by birth and colour. In their hearts and behaviour they are foreigners to African mode of life.

History is an essential part of identity of a people and by denying one's identity, one is thwarting the historical process. The blame for this crisis of identity could be shifted far back to the era of slavery and the advent of the colonial masters. However, the modern day Nigerian who, despite the fact that there is no more slavery and the colonial masters are gone, still finds it difficult to feel and be Nigerian is to be blamed.

\subsection{Loss of Identity through Slavery}

Slavery is one of the evils that have happened to the human race in history. It is known by all the races in the world and many practiced it in some way or the other. Nigeria as a country experienced this evil for many years. In Nigeria, during the slave era, there were many ways of becoming a slave. For example, all captives of war, convicted criminals and debtors who were unable to pay up their debts were all taken as slaves by either their conquerors or their lenders. However all those Nigerian slaves who found themselves within the soil of Africa were still within their cultural environment. The problem of loss of identity through slavery started with the trans-Atlantic slavetrade whereby the slaves were sold and exported off to Europe and America. "The Portuguese were the first to come to the coast of Africa in search of gold. However, when they could not find gold and sent a cargo of slaves to Lisbon, who were sold at great profit, they soon realized that trade in African slaves would be a very good business." (Iloh, 2006: 54). With the Portuguese trading in human beings as slaves, the trade spread across to other regions. Thus before the $16^{\text {th }}$ Century many merchants who were interested in African slaves grew in number. Thus "...Pirates 
from Britain, France, Denmark, Germany, Sweden, Portugal, Spain and Holland were all barrel und stock in the trade on slaves - all had countless slave ports in Africa..." (Iloh 2006: 55). African slaves were preferred more than the others because: "The people are more insensible than others towards pain and natural evils, as well as towards injuries and unjust treatment. In short, there is none so well adapted to be slaves of others." (Davidson, 1961, in Iloh, 2006: 55). With the transportation of those Nigerians and other African slaves across their boarders, they were forced to abandon their cultures and mentality and adopt those of their new masters.

It is important to note that identity was lost through colonialism. At first, the slave masters were not interested in colonizing Africa. Their interest was more in slave trading because it served a good purpose then. Besides, it was unthinkable to live in Africa because of Malaria which killed most of them. But with the development of anti-malaria medications the interest to live in Africa then arose, thus leading to colonialism.

\subsection{Loss of identity through Colonialism}

Colonialism in Igbo land is dated far back in the $18^{\text {th }}$ century. This shows that it has a long history that dominated the African continent for a long time. This practice led to the spread of the cultural values of the colonizing countries to the detriment of cultures of those that are being colonized. In order to exert a full authority over the people being colonized, the masters needed to suffocate their subjects with whatever values they have which they think will help them to rule and control them very well. Thus colonialism can be seen as a consequence of imbalance in power and a result of inequality among peoples.

In Nigeria, colonialism brought in some advantages and disadvantages as well. For instance, it brought in western education to the people and helped them to expand their world view. At the same time, it deprived the people of their freedom and robed them of their cultural identity. In Nigeria, colonialism enforced the imperial and foreign mentality and rule on the people. In many countries of Africa that were under the rule of the colonial masters, the impression of the Western colonial masters about them was that they were racially, religiously, mentally and culturally inferior and to bring them out of the shackles of darkness, they have to drop their values and imbibe those of the Westerners and by so doing, Africa lost most of their identities. This could be seen as the greatest evil of colonialism - the loss of identity. This is the case with Nigeria where colonialism led to the destruction of the culture and local civilization. This could be referred to as cultural conquest which aims at convincing the invaded that their values are intrinsically inferior (Freire, 1968). In Nigeria, the indirect rule system of government by the colonial masters did not regard the people's way of life and traditional values as something that has any value.

The pattern of leadership in the colonial era has been assimilated by the modern day African leaders. In Nigeria the colonial mentality of Master-slave relationship whereby the leader is the one who is to be served is seen very clearly. The leaders in Nigeria, like the old colonial masters, enjoy every privilege the state can offer. They are shielded from their subjects through long bureaucracy and security details. In fact, they are not in touch with the common folk. In Nigeria, the order of the day for the rich ones or those who can afford it is to employ lots of domestic workers - drivers, cooks, cleaners, security men, gardeners, personal assistants, etc. These employees are paid very little for so much work. This is a practice borrowed from the colonial mentality and arrogance.

\subsection{Loss of Identity through migration}

With the slave-trade and the coming of the colonial masters to the soil of Africa, the road for migration was created. Since the end of World War II, Europe has progressively shifted from being a major source of emigration to becoming a major destination for immigrants (Marozzi, 2015). Before the advent of the slave trade and the colonial rule, Nigerians never knew of the existence of the western world. It is a common joke among some Africans that they are migrating abroad to bring back what the Westerners took from them. But the fact remains that most of those who migrate are not willing to go back. More Nigerians are ready to leave the country in search of greener pastures. Such exodus of the masses does not only constitute loss of identity but also 
great loss of manpower for the development of the country.

Exchange of ideas and technical know-how is not bad in itself. Many Nigerian professionals who migrate to the western world to take up jobs are doing so because of the better salaries. Those who have made it to the developed world are expected not to lose sight of the fact that they are Africans. A medical doctor who abandons his clinic to work abroad; a university professor who leaves his job to teach in a high school abroad; a business man who closes his shop to work in a slum abroad etc, are all losses to the African society. This could be referred to as second slavery. This type of slavery is voluntary and more detrimental to the mentality and culture of Africa. This is because in the first slavery, the slaves were taken away by force and they wished to return. In this second form of slavery, the Africans give themselves up for enslavement (Teske \& Nelson, 1974). In the old form of slavery the victims are sold officially and their owners are known but in the modern form, the victims are sold unofficially through deception and threats (Huland, 2012). ${ }^{3}$ The captors are not known. The victims of the modern slavery accept any type of work under any condition and refuse any attempt to return to their home countries. Most would willingly deny their nationalities and claim other nationalities just to avoid returning to their native home.

Migrating for many reasons has been the lot of many Africans and Nigerians in particular. The women have also joined in this mass exodus and many ignore the shame of doing any kind of job and take the risks as the best option for them. When considered from the point of view of African cultural values, it is a great shame to know that a big number of Africans are prostitutes in the socalled developed world. This is a loss of identity because it is not part of the cultural values of Africa.

\section{Lack of Identity through Imitation of the Western Life-Style}

The Igbos have great admiration for the white man's life-style. Many of them mimic, imitate and act like the 'white man'. For instance: eating the 'white man's' type of food, wearing his type of clothes and speaking his language like he does are aspirations of many. It is a fact, but a regrettable one to note, that the western culture is seen as an embodiment of beautiful values which 'must' be imitated or at least admired. To be referred to as one who 'acts like a 'white man' is seen as a compliment in the Igbo society. This is a salient call to abandon the traditional life-style and an invitation to adopt the western life style. On the other hand, to be referred to as 'an Igbo man' or "an African man" is seen as insult and for a product to be referred to as such is seen as an indication that the product may be 'inferior'. These trends need to end for there to be a clear development in the lgbo or African society.

Many lgbos are imitating the western life style to the detriment of their traditional ones. This is as a result of exposure to and contact with the western life-style either by having a first-hand experience of these foreign cultures or by reading, hearing, and seeing them in the media. Certain customs, like marriage and hospitality, are no longer being held as sacred. As Nathaniel Ndiokwere (1998) writes: "In his bid to gain acceptance and hence succeed in his new home or community, an Igbo man can engage any woman within his reach in marriage.... As long as she is willing, the prospective Igbo husband does not mind accepting her in marriage in spite of her limitations and possible discrepancies in culture." (Ndiokwere, 1998: 55). The Igbo hospitality which is regarded and cherished very much in the culture is being replaced with the individuality of the western culture. Many make extra effort to learn the foreign accent which they, sometimes, apply while speaking their vernacular language.

\section{Language in Jeopardy}

Language has two functions in the theory of Sheyholislami (2010). Thus: Instrumental and Symbolic. While the instrumental function refers to the communicative aspect, the symbolic function refers to the representative meaning it embodies "as a marker of culture and identity." (Donkor, 2016).

\footnotetext{
${ }^{3}$ Translation mine.
} 
Through the imitation of the western life style, the Igbos have lost their language. It is very difficult to see an Igbo man speak or discuss with another Igbo without a mixture of one or two foreign languages. The fluency with which this mutilated language is being spoken suggests the extent of the damage to the original Igbo language. Sometimes the foreign languages (in most cases English) appear more than the local Igbo language in a sentence. For example: Kedu time anyi ga-eji wee move to the place? Meaning: What time are we going to move to the place? Quite typical of Igbo man, he adapts to every/any condition, and the more languages he learns, the more mutilated his original Igbo language becomes. In Austria, it is very interesting to observe the Igbos discuss together. There is usually a mixture of English, Deutsch and Igbo languages. For example: kedu time anyi ga a feier die Party? Meaning: um welche Uhr Zeit ist die Party? (What time is the party?).

Many who have lived for a long time in foreign countries have adapted the foreign language so much that they cannot avoid its influence while trying to use their vernacular langauge. Most of these influences are so foreign that the meanings of the words and sentences are lost. The situation is worst with the children born to these people. Some do well to give their children Igbo names but the bearers of these names do not know their meanings and are not able to pronounce them well or know how to pronounce them at all. Some second and third generation lgbos in Austria understand their parents vernacular, especially if it is spoken at home, while others understand only English and Deutsch because it is the means of communication at home.

\section{Identity in the Service of Development}

It is not to be denied that the westerners are good in management and have achieved a lot but the contributions of the undeveloped countries are not be ignored at the same time. That there are lacks in documentations and written histories do not underscore the efforts made by Africans to develop their continent. Africa has a system of leadership before the advent of the colonial masters. There were some powerful kings then. Some ancient civilizations and cultures found in Africa may be older than those of the Greek and Roman empires.

The lost identity of African sons and daughters has to be restored for further developments. The artefacts stolen or confiscated from Africa by the Westerners are evidences of the ingenuity of the African artists. The literary contributions of African authors are signs of the intellectual prowess of Africans. Rediscovering the Identity and putting it to the service of development in the African continent is the task of the Africans themselves. Ndiokwere (1998) puts it thus: "Unfortunately Africans have contributed to a great measure, by commission or omission to the exaltation of the white man, often to the detriment of the black race." (Ndiokwere, 1998: 124).

Hardship and poverty can be an advantage in disposing one for survival in the most difficult situation. This is the case with the Igbos. During the Nigeria/Biafra civil war, the Igbos showed the stuff they were made of by manufacturing weapons from locally sourced materials. Unfortunately these Engineers were never encouraged thereafter to further their researches in technology. Because of their astuteness, many Igbo medical doctors have performed complicated fits in the medical field with their poor equipment. Some goods that were manufactured locally, though not as qualitative as the foreign ones, can compete with their foreign counterparts in some ways.

The perpetuation of the cult of mediocrity will not help to build a solid Igbo society. In understanding the full identity of the Igbos, a lot has to be put into consideration. Acceptance of an inferior status will not help in any way. For example, taking the issue of "African Time" from its origin; this is a white man's invention. Before the advent of the white man, the Africans (Igbos) had a good concept of time. Though they had no watches as at that era, the sun and shadows were used to regulate their hours. Once a meeting or appointment is arranged, people were expected to be punctual and late comers were fined. This is an identity that could be reawakened in the mentality of the people today.

\section{The Path towards a Hybrid Identity}

Perhaps we may say that to talk about "loss of identity" in referring to the situation of the Africans 
(Igbos) with regard to their cultural heritage is to use the wrong expression. In maintaining that Africans have lost their identity due to contact with the western culture is an over-statement. Such contacts with the western culture could be seen as an avenue for the enrichment of the cultural values of both societies. Something can be learnt by the co-mingling of the two cultures and something can be lost too. Most of the modes of behaviour, be it dressing, eating, cooking, speaking, general etiquette etc, are mixtures of both western and African cultures.

In the formation of identity, peoples' responses and behavioural patterns can be linked to their environment. For those who find themselves outside their home countries, affiliation to two cultures: homeland culture and host culture, can lead to a proper integration of the person which will open up a lot of possibilities for development (Sherry, 2015). Sherry (2015) holds the opinion that there are four strategies in relating to background culture and host culture. These are integration; assimilation; separation and marginalization. People who identify with both cultures on equal level are said to be integrated; those who identify with the home culture and not with the host culture are separated; those who identify with host culture and not with the home culture are assimilated; and those who don't identify with either culture are classified as marginalized. Some Nigerian Igobs living in Austria who were interviewed believed that their parent help them to assimilate into the Austrian society. Some do not see themselves as entirely Austrians even though they were born and live in the Austrian society. Thus they refer to themselves as "half Austrian and half Nigerian." Others polled accepted that since they learned about their heritage, they have come to see themselves as purely Nigerians. The ability to connect with one's heritage enables one to bring the values into the host society (Donkor, 2016).

In the Igbo society of today, it is very common to experience this "hybrid culture" in its fullest. Most people who were abroad have foreign wives or partners and thereby living a multi-cultural lifestyle. There is a mixture of culture in the modern attire of the Igbo man. One can find an Igbo man wearing a French suit with a local Igbo traditional cap on his head. It is also very common for Igbo women to wear the traditional dress with some combination of the western design. The language as already discussed (see no.8) is a clear example of a hybrid identity.

Since mixture of culture is almost inevitable, adaptation of these cultures is the best solution in finding an identity that can be truly African or Igbo and at the same time suit the quest of the people. This is so because to ask those men and women from Africa who live outside the continent to return home en masse will be difficult. Those wishing to travel out will not accept any plea not to do so. In fact, the search for a better opportunity is the ultimate goal of many people.

The issue of religious acceptance by the Igbos is a case of hybrid identity. In his book Things Fall Apart, Chinua Achebe (1958) was able to shed light on the Igbo culture and the outside world were able to read about the Igbo society as revealed by their way of life, customs and traditions before the advent of the white man. Though the Igbo people of Things Fall Apart were primitive, their system of leadership and government was good. In their bid to know more and engage in adventure, the Igbo people allowed the white man to settle among them. With his cleverness and mentality, the white man cut the rope of unity among the Igbos, dismissed their cultures as primitive and evil and implanted his own in place of theirs. The Igbos therefore abandoned a lot of their cultural practices, thereby losing their identity and embraced those values they found in the white man's life especially in matters of religion and government. Thus, the Christian religion and the system of government found all over Africa and in the Igbo society today is a hybrid identity which is a mixture of the traditional African method and that of the Western.

\section{Conclusion}

Identity is a mark of a given people. This can be lost through many means of which migration is one of them. Culture and mentality help to build up the identity of a people and in the case of the Igbo people of South-Eastern Nigeria, their cultural identity has been greatly mutilated by their comingling with other cultures both within and outside Nigeria.

\footnotetext{
${ }^{4} 3$ of the people polled maintained that they are dont know whether to call themselves Nigerians or Austrians and so concluded: "we think that we are both."
} 
There are rich cultural values to be gained due to contact with other cultures and, in the case of adapting a "hybrid identity", the exchange of ideas and technology can help in the physical development and discipline of the society. There are, however, some aspects of the behavioural pattern of a society that need not be emulated for any reason. For example, violent aspects and moral delinquencies are not to be incorporated into the "hybrid identity". Although these violent and moral issues are not part of any culture, some young ones find them easy to copy. To identify one's origin and to be associated with one's cultural values is a great honour.

In any study on the development of Africa, there ought to be emphasis on the African people recognizing their identity and bringing it into play. The Africans themselves are encouraged re-think and rediscover those ancient values which the fore-fathers had and which helped them to hold their society close in spite of all odds. In the development of Africa, the problems are more or less not to be found from outside Africa but within: "The enemies are not the white people in their own countries and fatherlands. They are primarily African politicians in civil and military uniforms. The enemies of Africa are the economic saboteurs, those who steal and loot their countries' treasures, and bank their loot in foreign banks from where they withdraw and squander Africa's wealth while millions languish in poverty and lack of basic necessities of life." (Ndiokwere, 1998: 179). This situation calls for good leadership. Many Africans and indeed Igbo sons and daughters living and working abroad are not ready to return unless there are good leaders and security. The problems of Africa are compounded more by the negative impressions western countries have about Africa and this will be difficult to change unless the Africans and the Igbos indeed rediscover their identity.

\section{References}

Achebe, C. (1958). Things Fall Apart. UK: Heinemann Publishers.

Bauman, Z. (1992). Intimations of Postmodernity. London: Routledg.

Brockhaus Enzyklopädie. (2006). Autorengemeinschaft \& Redaktionelle Leitung. Leipzig: F.A. Brockhaus $\mathrm{GmbH}$, Bibliographisches Insitut \& F.A. Brockhaus AG.

Davidson, B. (1961). The African Slave Trade. In S. Iloh, (2006). The Face of Africa. Looking beyond the Shadows. Indiana: AuthorHouse.

Donkor, A.D. (2016). Assimilation and Social Success. Cultural Identity of Second Generation Nigerian Migrants in Oslo, Norway. [Online] Available: https://brage.bibsys.no/xmlui/bitstream/handle/11250/2413508 AVH5010-kand-nr-1104-masteravh-Donkor-navn.pdf?sequence=1\&isAllowed=y. (December 16, 2017).

Esteva, G. (1991). "Preventing Green Redevelopment”. Development - Journal of SID, N0.2, 74 -78.

Esteva, G. (2006). The Revolution of the New Commons. Motion Magazine April 8, 2006. [Online] Available: http://www.inmotionmagazine.com/global/gest_int_4.html. (November 3, 2017).

Freire, P. (1968). Pedagogy of the Oppressed. M. Bergman-Ramos. (Transl.). New York: The Seabury Press.

Frey, H. P. (1987). Identität. Entwicklungen psychologischer und soziologischer Forschung. Stuttgart: Enke.

Huland, A. (2012). Frauenhandel in Deutschland. Marburg: Tectum Verlag.

Ikeh, F. O. (1986). Value Meaning and Social Structure of Human Work. Frankfurt: Peter Lang Verlag.

Iloh, S. C. (2006). The Face of Africa. Looking Beyond the Shadows. Indiana: AuthorHouse.

Köck, P. \& Ott, H. (1994). Wörterbuch für Erziehung und Unterricht. Donauwörth: Verlag Ludwig Auer Verlag.

Krappmann, L. (1993). Soziologische Dimension der Identität. Strukturelle Bedingungen für die Teilnahmen an Interaktionsprozessen, 8 Auflage. Stuttgart: Klett-Cotta.

Marozzi, M. ( 2015). Construction, Robustness Assessment and Application of an Index of Perceived Level of Socio-economic Threat from Immigrants: A Study of 47 European Countries and Regions. Social Indicators Research.

Mead, G. H. (1998). Geist, Identität, und Gesellschaft. Aus der Sich des Sozialbehaviorismus. 11 Auflage, Frankfurt/M.

National Population Commission. (2017). [Online] Available: http://population.gov.org.

Ndiokwere, N. (1998). Search for Greener Pastures. Igbo and African Experience. Nebraska USA: Morris Publishing.

Reinhold, G. (1992). Soziologie-Lexikon. München: R. Oldenbourg Verlag.

Sherry, T. (2015). Identification and Identity. New York: Kenhills Publishers.

Teske, R.H. \& Nelson, B.H. (1974). Acculturation and assimilation: A clarification. American Ethnologist, 17. 218-235.

Ziai, A. (2000). Globalisierung als Chance für Entwicklungsländer? Ein Einstieg in die Problematik der Entwicklung in der Weltgesellschaft. Münster: LIT. 